\title{
МАЙБУТНЕ ПІСЛЯДИПЛОМНОЇ ОСВІТИ: БОЛОНСЬКИЙ ПРОЦЕС ЧИ КРЕДИТНО-МОДУЛЬНА СИСТЕМА?
}

\author{
В. К. Івченко, В. В. Сімрок, Ю. І. Налапко \\ Державний заклад “ Луганський державний медичний університет”
}

\section{THE FUTURE OF POST-GRADUATE EDUCATION: BOLOGNA PROCESS OR CREDIT-MODULAR SYSTEM?}

\author{
V. K. Ivchenko, V. V . Simrok, Yu. I. Nalapko \\ State Establishment "Luhansk State Medical University"
}

\begin{abstract}
Обговорено перспективи впровадження основних принципів Болонської декларації у вищу післядипломну медичну освіту України. Показані позитивні риси застосування кредитно-модульної системи в підготовці лікаря в інтернатурі.
\end{abstract}

Perspectives of implementation of basic principles of Bologna declaration into medical post-graduate education of Ukraine were discussed. Positive signs of use of credit-modular system in education of doctors in the internship were shown.

Вступ. Червень 2011 року ознаменується важливою подією для вищої медичної школи України - випуском спеціалістів, які пройшли наскрізний курс навчання на додипломному етапі за кредитно-модульною системою організації навчального процесу. Наразі постає питання спадкоємності у формах та методах навчання даного контингенту випускників на післядипломному етапі.

Основна частина. Жоден нормативно-правовий документ, прийнятий в Україні в рамках заходів щодо приєднання до Болонської декларації, не містив зобов' язань вищої школи, в тому числі медичної, запроваджувати такі засади на післядипломному етапі [5]. Проте дане питання вільно чи мимоволі постійно обговорюється на форумах різного рівня, в тому числі на Всеукраїнських навчально-наукових конференціях [3]. Заклади та факультети післядипломної медичної освіти, приймаючи в інтернатуру випускників “болонського формату”, замислюються над тим, які педагогічні та організаційні новели очікуватимуть їх протягом найближчого часу.

Основним лозунгом Болонської декларації є досягнення високого рівня підготовки спеціалістів шляхом забезпечення їх мобільності в країнах, що прийняли дану декларацію, та уніфікації програм і форм навчання студентів.

Аналіз цих завдань показує, що в Україні, попри існування Типових програм і планів навчання в інтернатурі, наразі немає умов для уніфікації графіків навчання інтернів в різних університетах. Перш за все, це пов'язано з тим, що проведення тих чи інших клінічних модулів на очному циклі інтернатури залежить від наявності профільних хворих в клініці, вивчення навчальних тем, що внесені навчальним закладом в Робочу програму в межах допустимої варіативної частини навчання, розкладом занять на суміжних циклах, вивченням додаткових дисциплін тощо. Слід визнати, що сьогодні уніфікований графік навчання інтерна відсутній в межах навіть двох сусідніх медичних університетів, не говорячи про національну модель.

3 відсутності уніфікованості навчання інтерна випливає друге важливе обмеження впровадження принципів Болонського процесу на післядипломному етапі - мобільності осіб, що навчаються. На відміну від додипломного навчання, де механізм переведення до інших вишів чітко регламентований, лікар (провізор)інтерн в законодавчому сенсі обмежений у своїй мобільності. Насамкінець, при підвищених (а іноді неможливих) вимогах контролюючих органів щодо доїзду молодих спеціалістів до першого місця роботи університет не має мотивації стимулювати мобільність інтернів, якщо це не короткочасне стажування або участь в програмах обміну з закордонними університетами.

Таким чином, є підстави стверджувати, що післядипломна освіта повинна дуже обережно підходити до впровадження принципів Болонської декларації в повсякденну роботу. 
Та чи означає це, що факультети післядипломної освіти не можуть нічого взяти корисного $з$ досвіду додипломного етапу навчання останніх 6 років? Звичайно, ні. Слід чітко розуміти, що кредитно-модульна система організації навчального процесу, хоча $\mathrm{i}$ впроваджена в медичних вишах разом з приєднанням до Болонської декларації, є самодостатнім педагогічним інструментом, який дозволяє успішно вирішувати питання якісного, структурно орієнтованого та практично мотивованого процесу навчання i підготовки компетентного спеціаліста. Більшість елементів кредитно-модульної системи на післядипломному етапі впроваджена ще до того, як вони прийшли на додипломний етап $[1,4]$. Так, інтернатура передбачає на кожному році навчання два великих модулі - очний та заочний етапи, кожний з яких має конкретну мету, структурні завдання, індивідуальні форми навчання вихідний, поточний та заключний аналіз рівня підготовки. В свою чергу будь-яка спеціальність, за якою проходить підготовка в інтернатурі, містить низку модулів, які інтерн в будь-якому порядку (який визначає викладач та базовий керівник залежно від клінічної ситуації та інших обставин) має пройти, оволодіти певним переліком навичок, виконати визначену кількість маніпуляцій тощо. Цим досягається структурованість викладання, етапність контролю та завершеність сприйняття дисципліни в цілому.

Використання кредитів на післядипломному етапі сьогодні не передбачене. Звичайно, їх можна впровадити в будь-який час, але перед цим слід з'ясувати доцільність цього кроку, адже це питання не $\epsilon$ цілком зрозумілим і на додипломному етапі. Креди-

\section{Лiтература}

1. Формально-логічний аналіз кредитно-модульного процесу в контексті його ресурсного забезпечення в системі підготовки медичних спеціалістів/ Г. В. Бесполудіна, Ю. І. Налапко, А. В. Жила, О. А. Козікова // Впровадження кредитно-модульної системи організації навчального процесу у $\mathrm{BM}(\Phi) Н 3$ України : результати, проблеми та перспективи : матеріали Всеукраїнської навчально-наукової конференції 3 міжнародною участю (Тернопіль, 20-21.05.2010 р.). Тернопіль: Укрмедкнига, 2010. - С. 399-400.

2. Івченко В. К. Післядипломна медична освіта в Великобританії : перспективи для Національної системи безперервного професійного розвитку / В. К. Івченко, Ю. І. Налапко // Досвід та проблеми впровадження кредитно-модульної системи навчання у вищих медичних та фармацевтичних навчальних закладах України: матеріали Всеукраїнської навчально-наукової конференції (Тернопіль, 15-16.05.2008 р.). - Тернопіль : Укрмедкнига, 2008. - C. 183-185. тами можна вважати кількість балів, які лікар повинен набрати в міжатестаційний період.

В цілому аналіз підготовки майбугнього лікаря на додипломному та післядипломному етапі за кордоном, зокрема у Віденському медичному університеті, Імперському коледжі Лондона, Університетському коледжі Лондона, Університеті Гамбурга, де автори мали власний досвід вивчення системи медичної освіти, свідчить про спільність форм і методів організації навчання з тими, що впроваджені в Україні [2]. Навіть проблеми системи вищої медичної освіти є дуже схожими: недостатність фінансування, взаємовідносини університету та клінічної бази (територіальне питання та оренда), оплата праці практикуючого лікаря за навчання інтерна (резидента) тощо. Однак $\epsilon$ напрями, які сьогодні вже впроваджені в Свропі та показали перспективність у підготовці якісного спеціаліста:

- розвиток дистанційних форм навчання;

- ситуаційні форми екзаменування (OSCE, SOE);

- оцінка не тільки широти, а й глибини знань інтерна (VIVA);

- залучення професійних асоціацій до атестаційного процесу з визначенням їх подальшої відповідальності за підготовку інтерна тощо.

Висновок. Зазначені вище напрями $\epsilon$ першочерговими в розвитку вищої медичної післядипломної освіти. Найголовнішою умовою підготовки кваліфікованого та компетентного спеціаліста в інтернатурі, поряд із зусиллями університету, слід вважати мотивацію студента та інтерна до отримання якісної освіти, конкурентні умови працевлаштування на високооплачуваних посадах, соціальну захищеність лікаря, престижність професії та повагу з боку держави.

3. Проблеми та шляхи підвищення якості підготовки лікарів-інтернів відповідно до вимог Болонської декларації/ В. І. Кривенко, С. П. Пахомова, О. П. Федорова, І. В. Непрядкіна // Досвід та проблеми впровадження кредитномодульної системи навчання у вищих медичних та фармацевтичних навчальних закладах України: матеріали Всеукраїнської навчально-наукової конференції(Тернопіль, 15-16.05.2008 p.).Тернопіль: Укрмедкнига, 2008. - С. 189-190.

4. Москаленко В. Ф. Особливості безперервного професійного розвитку лікарів в сучасних умовах / В. Ф. Москаленко, А. С. Свінціцький // Післядипломна медична освіта : досвід і перспективи : матеріали науково-методичної конференції, присвяченої 85-річчю ХМАПО (Харків, 2-3.10.2008 р. ). - Харків, 2008. - С. 10-12.

5. Степко М. Ф. Болонський процес у фактах і документах / М. Ф. Степко, Я. Я. Болюбаш. - Київ-Тернопіль : Видво ТДПУ, 2005.-52 с. 